\title{
COMPLICATIONS AFTER PARTIAL, TOTAL OR EXTENDED SACRECTOMY: A CASE SERIES
}

\author{
COMPLICAÇÕES DEPOIS DE SACRECTOMIA PARCIAL, TOTAL OU ESTENDIDA: SÉRIE DE CASOS
} COMPLICACIONES DESPUÉS DE SACRECTOMÍA PARCIAL, TOTAL O EXTENDIDA: SERIE DE CASOS

\author{
Danilo de Souza Ferronato ${ }^{1}$, Mauro Costa Morais Tavares Junior ${ }^{1}$, Douglas Kenul Narazaki ${ }^{2}$, Cesar Salge Ghilardi², Willam Gemio Jacobsen Teixeira², \\ alexandre fogaça Cristante ${ }^{1}$, tarcisio Eloy Pessoa de Barros Fillo ${ }^{1}$
}

1. Instituto de Ortopedia e Traumatologia do Hospital das Clínicas da Faculdade de Medicina Universidade de São Paulo, São Paulo, SP, Brazil.

2. Instituto do Câncer do Estado de São Paulo. Department of Spine Surgery, São Paulo, SP, Brazil.

\begin{abstract}
Objective: The aim of this study was to conduct a survey of the different complications of partial, total or extended sacrectomy for the treatment of spinal tumors. Method: This study is a descriptive analysis of medical records from a series of 18 patients who underwent sacrectomy between 2010 and 2019 at a tertiary center specializing in spinal tumor surgeries. The variables analyzed were sex, age, hospitalization time, oncologic diagnosis, posterior fixation pattern, rate of complications, and Frankel, ASA and ECOG scales. Results: Of the 18 patients, 10 $(55.5 \%)$ were male and 8 (44.5\%) were female, and the mean age was 48 years. The mean hospitalization time was 23 days. Of the 18 patients, $8(44.5 \%)$ contracted postoperative infections requiring surgery. Perioperative complications included liquoric fistula (22.25\%), hemodynamic instability requiring vasoactive drugs in the immediate postoperative period (22.25\%), wound dehiscence (11.1\%), acute obstructive abdomen (11.1\%), occlusion of the left external iliac artery (11.1\%), immediate postoperative death due to acute myocardial infarction (11.1\%), and intraoperative death due to hemodynamic instability (11.1\%). Conclusions: Partial, total or extended sacrectomy is a complex procedure with high morbidity and mortality, even in centers specializing in the treatment of spinal tumors. Level of evidence IV; case series study.
\end{abstract}

Keywords: Sacrum; Spinal Neoplasms; Intraoperative Complications; Postoperative Complications.

\section{RESUMO}

Objetivo: O objetivo deste estudo é fazer um levantamento das diferentes complicações da sacrectomia parcial, total ou estendida para tratamento de tumores da coluna vertebral. Métodos: O estudo é uma análise descritiva de prontuários de uma série de 18 pacientes submetidos à sacrectomia entre 2010 e 2019 em um centro terciário especializado em cirurgias de neoplasia na coluna. As variáveis analisadas foram sexo, idade, tempo de internação, diagnóstico oncológico, padrão de fixação posterior, taxa de complicações e escalas de Frankel, ASA e ECOG. Resultados: Dos 18 pacientes, 10 (55,5\%) eram homens e 8 (44,5\%) mulheres com média de idade de 48 anos. 0 tempo médio de internação foi de 23 dias. Dos 18 pacientes, 8 (44,5\%) contraíram infecções pós-operatórias com necessidade de cirurgia. As complicações perioperatórias incluíram fistula liquórica (22,25\%), instabilidade hemodinâmica com necessidade de medicação vasoativa no pós-operatório imediato (22,25\%), deiscência da ferida operatória (11,1\%), abdome obstrutivo agudo (11,1\%), oclusão da artéria ilíaca externa esquerda (11,1\%), óbito pós-operatório imediato por infarto agudo do miocárdio (11,1\%) e óbito intraoperatório por instabilidade hemodinâmica (11,1\%). Conclusões: A sacrectomia parcial, total ou estendida é um procedimento complexo com alta taxa de mortalidade e morbidade, mesmo em centros especializados no tratamento de tumores na coluna. Nível de evidência IV; Série de casos.

Descritores: Sacro; Neoplasias da Coluna Vertebral; Complicações Intraoperatórias; Complicações Pós-operatórias.

\section{RESUMEN}

Objetivo: El objetivo de este estudio es evaluar las diferentes complicaciones de la sacrectomía parcial, total o extendida para el tratamiento de tumores vertebrales. Métodos: El estudio es un análisis descriptivo de las historias clínicas de 18 pacientes sometidos a sacrectomía entre 2010 y 2019 en un centro terciario especializado en cirugías de neoplasia de columna. Las variables analizadas fueron sexo, edad, estancia hospitalaria, diagnóstico de cáncer, patrón de fijación posterior, tasa de complicaciones, escalas de Frankel, ASA y ECOG. Resultados: De los 18 pacientes, 10 (55,5\%) eran hombres y 8 (44,5\%) mujeres con una edad promedio de 48 años. La estancia hospitalaria promedio fue de 23 días. De los 18 pacientes, 8 (44,5\%) contrajeron infecciones posoperatorias que requirieron cirugía. Las complicaciones perioperatorias incluyeron fístula de líquido cefalorraquídeo (22,25\%), inestabilidad hemodinámica que requirió medicación vasoactiva en el posoperatorio inmediato (22,25\%), dehiscencia de la herida quirúrgica (11,1\%), abdomen obstructivo agudo (11,1\%), oclusión de la arteria ilíaca externa izquierda (11,1\%), muerte posoperatoria inmediata por infarto agudo de miocardio $(11,1 \%)$ y muerte intraoperatoria por inestabilidad hemodinámica (11,1\%). Conclusiones: La sacrectomía parcial, total o extendida es un procedimiento complejo con una alta tasa de mortalidad y morbilidad, incluso en centros especializados en el tratamiento de tumores de la columna. Nivel de evidencia IV; Series de casos

Descriptores: Sacro; Neoplasias de la Columna Vertebral; Complicaciones Intraoperatorias; Complicaciones Posoperatorias. 


\section{INTRODUCTION}

Sacral tumors are rare and may be malignant or benign. They represent $1 \%$ to $7 \%$ of all tumors of the spine. In general, the response to chemotherapy and radiotherapy is not satisfactory for these tumors. ${ }^{1,2}$ En bloc sacrectomy is currently the recommended treatment for malignant sacral tumors. ${ }^{3-7}$ The term total sacrectomy refers to resection and attachment of the dural sac below bilateral S1, with the resection extending to $L 5, L 4$ and to the iliac region if necessary. ${ }^{3-7}$

Sacrectomies are complex ${ }^{8}$ and can have several complications. As the diagnosis of various sacral tumors is complicated and usually delayed, due to the slow and indolent growth of most tumors, it is usually made incidentally, or when the tumor is already at an advanced stage. ${ }^{9}$

Detailed knowledge of the local anatomy, and the appropriate choice of patient and surgical procedure by the multidisciplinary team, are very important for the success of the treatment and for achieving good functional outcomes. ${ }^{10}$

The main surgical complications include: wound dehiscence, sacral hernia, and the need for multiple surgical approaches to treat postoperative complications. ${ }^{1}$

Other difficulties encountered after sacrectomies are musculocutaneous reconstruction to cover the generated defect, for which the vertical rectus abdominis and the gluteal musculature flap are most commonly used. ${ }^{11}$ In addition, postoperative radiation therapy is often necessary, which increases the likelihood of wound complications in the postoperative period. ${ }^{12}$

The primary objective of this study was to conduct a survey of the various complications of partial, total or extended sacrectomy at a center specializing in spinal tumor surgeries. The secondary objective was to analyze clinical and neurological function, hospitalization time, and fixation pattern.

\section{METHODS}

This is a case series of medical records of a series of 18 patients treated for sacral tumors between 2010 and 2019 at a tertiary center specializing in spinal tumor surgeries.

The variables analyzed were sex, age, hospitalization time, oncologic diagnosis, posterior fixation pattern, rate of complications, and Frankel, ASA and ECOG scales.

The inclusion criteria were: patients older than 17 years of age, of both sexes, who underwent sacrectomy (partial, total or extended). The exclusion criteria were patients with incomplete demographic data records.

This study was approved by the ethics committee (NP 1544/19), and patient consent was not required.

\section{RESULTS}

Eighteen surgeries were performed between 2010 and 2019; 10 patients were male, and 8 were female, with a mean age of 48 years.

The oncologic diagnoses were as follows: 6 chordomas, 3 chondrosarcomas, 1 peripheral nerve sarcoma, 1 malignant fibrous histiocytoma, 2 giant cell tumors, 1 Ewing's sarcoma, 3 schwannomas, and 1 osteoblastoma.

Regarding the extent of the sacrectomy, the following procedures were performed: total + L5 (5 cases), total + L4 (3 cases), total + L5 + partial iliac (1 case), and partial sacrectomy (9 cases).

In a third of the cases, grafts (vascularized: 1, allograft: 5) were used. The mean hospitalization time was 23 days.

Of the 18 patients, 8 (44.5\%) contracted a postoperative infection requiring surgery. Perioperative complications included: 2 (22.25\%) instances of liquoric fistula, 2 (22.25\%) instances of hemodynamic instability requiring vasoactive drugs in the immediate postoperative period, 1 (11.1\%) wound dehiscence, 1 (11.1\%) acute obstructive abdomen, 1 (11.1\%) occlusion of the left external iliac artery, 1 (11.1\%) immediate postoperative death due to acute myocardial infarction, and $1(11.1 \%)$ intraoperative death due to hemodynamic instability. A summary of the results is shown in Table 1.
Figure 1 shows the final appearance after tumor resection and posterior fixation.

Table 2 shows the Frankel, ASA (American society of anesthesiologist scale) and ECOG (eastern cooperative oncology group performance status) scores in the preoperative assessment.

Table 1. Summary of demographic and clinicopathological data of individuals submitted to sacrectomy.

\begin{tabular}{|c|c|}
\hline Variable & $\mathbf{N}(\%)$ \\
\hline Mean Age (years) & $48(100)$ \\
\hline \multicolumn{2}{|l|}{ Sex, n (\%) } \\
\hline Female & $8(44.5)$ \\
\hline Male & $10(55.5)$ \\
\hline \multicolumn{2}{|l|}{ Oncologic Diagnosis } \\
\hline Chordoma & $6(33.4)$ \\
\hline Chondrosarcoma & $3(16.7)$ \\
\hline Schwannoma & $3(16.7)$ \\
\hline Giant cell tumor & $2(11.2)$ \\
\hline Peripheral nerve sarcoma & $1(5.5)$ \\
\hline Malignant fibrous histiocytoma & $1(5.5)$ \\
\hline Ewing's sarcoma & $1(5.5)$ \\
\hline Osteoblastoma & $1(5.5)$ \\
\hline \multicolumn{2}{|l|}{ Extent of Sacrectomy } \\
\hline Partial & $9(50)$ \\
\hline Total + L5 & $5(27.8)$ \\
\hline Total + L4 & $3(16.7)$ \\
\hline Total + L5 + partial Iliac & 1 (5.5) \\
\hline \multicolumn{2}{|l|}{ Graft } \\
\hline Vascularized & 1 \\
\hline Allograft & 5 \\
\hline \multicolumn{2}{|l|}{ Posterior Fixation } \\
\hline Yes & $8(44.5)$ \\
\hline No & $10(55.5)$ \\
\hline \multicolumn{2}{|l|}{ Infection } \\
\hline Yes & $8(44.5)$ \\
\hline No & $10(55.5)$ \\
\hline
\end{tabular}
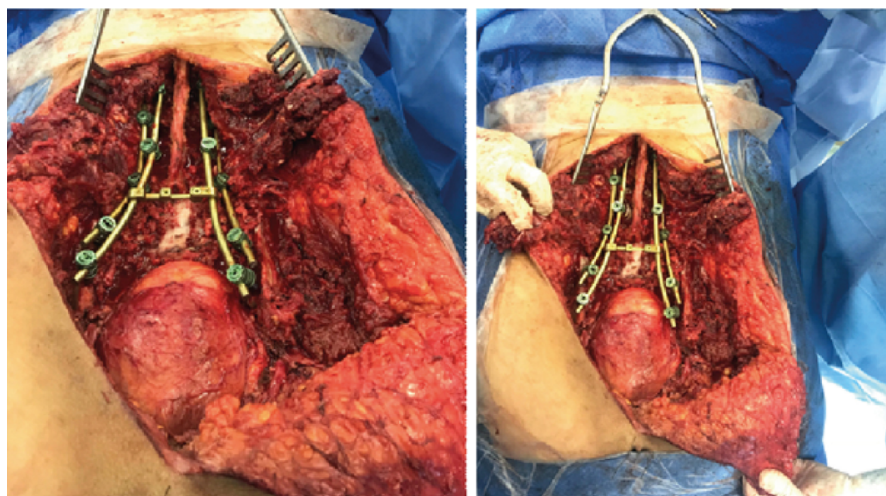

Figure 1. Final appearance after tumor resection and posterior fixation.

Table 2. Frankel, ASA and ECOG values.

\begin{tabular}{c|c}
\hline Variable & $\mathbf{N}(\%)$ \\
\hline Frankel & $18(100)$ \\
\hline$D$ & $6(33,3)$ \\
\hline E & $12(66,7)$ \\
\hline ASA & $2(11,2)$ \\
\hline I & $9(50,0)$ \\
\hline II & $7(38,8)$ \\
\hline III G & $5(27,8)$ \\
\hline 1 & $11(61,1)$ \\
\hline 2 & $2(11,2)$ \\
\hline 3 & \\
\hline
\end{tabular}

$\mathrm{ASA}=$ American Society of Anesthesiologists scale. ECOG = Eastern Cooperative Oncology Group performance status scale. 


\section{DISCUSSION}

The sacral spine is often affected by different types of tumors. Several classifications are used to determine the proposed treatment. One of these is the Weinstein-Boriani-Biagini classification. In this system, an axial section of the spine is used as reference, subdividing the zones clockwise, from $A$ to $E$ ( $A$ : extra-osseous soft tissue; B: intra-osseous superficial; C: intra-osseous deep; D: extra-osseous \{extradural\}; E: extra-osseous \{intradural\}). ${ }^{13,14}$

Vertebrectomy is indicated for lesions in zones 4-8, or 5-9 with at least one pedicle free of tumor. Sagittal resection is indicated for unilateral lesions from zones $2-5$ or $8-11$, with the lesion possibly involving the pedicle or transverse process. Sacrectomy is indicated for sacral lesions in which en bloc resection of the lesion is to be performed. ${ }^{15}$

There are several techniques for performing total sacrectomy. One widely used technique is performed in two stages. The first consists of a midline anterior incision, dissection of visceral/neural structures, and ligation of the internal iliac vessels, followed by an anterior L5-S1 discectomy. The second consists of mobilization of an inferiorly based myocutaneous rectus abdominis pedicle flap for wound closure, followed by an L5 laminectomy, bilateral L5 foraminotomy, ligation of the thecal sac, division of sacral nerve roots, and transection of the ilia lateral to the tumor and sacroiliac joints. ${ }^{16}$

The complication rates after sacrectomy are extremely high, reaching up to $60 \%$ of all cases, ${ }^{1,17}$ which is in agreement with the data found in the present study. The most common complication is infection at the surgical site, ${ }^{17,18}$ with rates of $13.2 \%$ in some series. ${ }^{19}$ Our series observed higher rates (44.5\%) compared to other works.

Regarding postoperative reconstruction patterns, a posterior approach with fixation is commonly used, with variations in the number of rods, or even no reconstruction after sacral resection. ${ }^{20-23}$ In the present study, 8 cases required posterior fixation, as shown in Table 1.
For the preoperative anesthetic and functional evaluations, the Frankel, ASA and ECOG scales were used. The Frankel scale ${ }^{24}$ assesses sensory and motor function, attributing a grade from $A$ (complete loss of function) to $E$ (normal). The ASA classification ${ }^{25}$ is used to assess the patient's physical status before surgery. The ECOG scale ${ }^{26}$ is used to analyze the patient's functional performance status, with values ranging from 0 (unrestricted to strenuous physical activities) to 5 (death). All the patients of the present study were physically functional and did not have comorbidities that would contraindicate surgery, as only levels $D$ and $E$ on the Frankel scale were observed; in relation to the ASA classification, classes IV and V were not observed. Regarding the functional aspects related to physical performance and quality of life assessed by the ECOG scale, the vast majority of patients were able to walk, whether at home or in the social environment, and had self-care capacity (ECOG score greater than or equal to 2).

Among the limitations of the study, we highlight its retrospective aspect, the lack of postoperative functional assessments, and the lack of assessment of risk factors associated with the complications reported. These evaluations will be the focus of future studies based on this work.

\section{CONCLUSIONS}

Partial, total or extended sacrectomy is a complex procedure with high morbidity and mortality, even when conducted at centers specializing in the treatment of spinal tumors.

All authors declare no potential conflict of interest related to this article.

CONTRIBUTION OF THE AUTHORS: DSF, MCMTJ, CSG, WGJT: carried out the literature review and wrote the project, collected and analyzed the data and wrote the manuscript. DKN, AFC, TEPBF: final review of the literature and project, designed the study, analyzed the data and reviewed the manuscript.

\section{REFERENCES}

1. García-Ortega DY, Clara-Altamirano MA, Gómez-Pedraza A, Martínez-Said H, Maciel-Miranda A, Caro-Sánchez CHS, et al. Tumores primarios de sacro: análisis de resultados y complicaciones [Primary sacral tumors: analysis of results and complications]. Acta Ortop Mex. 2018:32(6):354-57. Spanish. PMID: 31184007

2. Fourney DR, Rhines LD, Hentschel SJ, Skibber JM, Wolinsky JP, Weber KL, et al. En bloc resection of primary sacral tumors: classification of surgical approaches and outcome. $J$ Neurosurg Spine. 2005:3(2):111-22. https://doi.org/10.3171/spi.2005.3.2.0111.

3. Varga PP, Szoverfi Z, Lazary A. Surgical treatment of primary malignant tumors of the sacrum Neurol Res. 2014;36(6):577-87. https://doi.org/10.1179/1743132814y.0000000366.

4. Feldenzer JA, McGauley JL, McGillicuddy JE. Sacral and presacral tumors: problems in diagnosis and management. Neurosurgery. 1989;25(6):884-91. https://doi. org/10.1227/00006123-198912000-00006

5. Bydon M, De la Garza-Ramos R, Gokaslan ZL. Editorial: total sacrectomy for malignant sacra tumors via a posterior-only approach. J Neurosurg Spine. 2015;22(6):561-2. https://doi. org/10.3171/2014.11.spine141068.

6. York JE, Kaczaraj A, Abi-Said D, Fuller GN, Skibber JM, Janjan NA, et al. Sacral chordoma: 40-year experience at a major cancer center. Neurosurgery. 1999;44(1):74-9; discussion 9-80. https://doi.org/10.1097/00006123-199901000-00041.

7. Ozaki T, Flege S, Liljenqvist U, Hillmann A, Delling G, Salzer-Kuntschik M, et al. Osteosarcoma of the spine: experience of the cooperative osteosarcoma study group. Cancer 2002:94(4):1069-77. https://doi.org/10.1002/cncr.10258.

8. Varga PP, Szoverfi Z, Lazary A. Surgical resection and reconstruction after resection of tumors involving the sacropelvic region. Neurol Res. 2014;36(6):588-96. https://doi.org/10.1 179/1743132814y.0000000370.

9. Todd Jr LT, Yaszemski MJ, Currier BL, Fuchs B, Kim CW, Sim FH. Bowel and bladder function after major sacral resection. Clin Orthop Relat Res. 2002;(397):36-9. https://doi. org/10.1097/00003086-200204000-00006

10. Horan TC, Gaynes RP, Martone WJ, Jarvis WR, Emori TG. CDC definitions of nosocomia surgical site infections, 1992: a modification of CDC definitions of surgical wound infections. Infect Control Hosp Epidemiol. 1992;13(10):606-8. https://doi.org/10.2307/30148464.

11. Asaad M, Rajesh A, Wahood W, Vyas KS, Houdek MT, Rose PS, et al. Flap reconstruction for sacrectomy defects: A systematic review and meta-analysis. J Plast Reconstr Aesthet Surg. 2020;73(2):255-68. doi: 10.1016/j.bjps.2019.09.049. Epub 2019 Oct 11. PMID: 31757686.

12. Houdek MT, Rose PS, Hevesi M, Schwab JH, Griffin AM, Healey JH, et al. Low dose radiotherapy is associated with local complications but not disease control in sacral chordoma. J Surg Oncol. 2019;119(7);856-63.
13. Davis $\mathrm{JH}$. Anatomical classification and surgical considerations: primary spinal tumours an overview. SA Orthop. J. . 2011;:10(.3):26-30.

14. Boriani S, Weinstein,JN, BiaginiR.Primary Bone Tumors of the Spine. Spine. 1997;22(9), $1036-44$

15. Araújo TPF, Narazaki DK, Teixeira WGJ, Busnardo F, Cristante AF, de Barros Filho TEP. SACRECTOMY ASSOCIATED WITH VERTEBRECTOMY: A NEW TECHNIQUE USING DOWEL GRAFTS FROM CADAVERS. Acta Ortop Bras. 2018;26(4):260-64. doi: $10.1590 / 1413-785220182604183451$.

16. Gokaslan ZL, Romsdahl MM, Kroll SS, Walsh GL, Gillis TA, Wildrick DM, et al. Total sacrectomy and Galveston L-rod reconstruction for malignant neoplasms. Technical note. J Neurosurg. 1997;87(5):781-7. https://doi.org/10.3171/jns.1997.87.5.0781.

17. Biagini R, Ruggieri P, Mercuri M, Capanna R, Briccoli A, Perin S, et al. Neurologic deficit after resection of the sacrum. Chir Organi Mov. 1997:82(4):357-72

18. Nakai S, Yoshizawa H, Kobayashi S, Maeda K, Okumura Y. Anorectal and bladder function after sacrifice of the sacral nerves. Spine (Phila Pa 1976). 2000;25(17):2234-9. https://doi. org/10.1097/00007632-200009010-00015.

19. Li D, Guo W, Qu H, Yang R, Tang X, Yan T, et al. Experience with wound complications after surgery for sacral tumors. Eur Spine J. 2013; 22(9): 2069-76.

20. Randall RL, Bruckner J, Lloyd C, Pohlman TH, Conrad EU. Sacral resection and reconstruction for tumors and tumor-like conditions. Orthopedics. 2005;28(3):307-13.

21. Sahakitrungruang C, Chantra K, Dusitanond N, Atittharnsakul P, Rojanasakul A. Sacrectomy for primary sacral tumors. Dis Colon Rectum. 2009;52(5):913-8. https://doi.org/10.1007/ DCR.0b013e3181a0d932.

22. Sar C, Eralp L. Surgical treatment of primary tumors of the sacrum. Arch Orthop Trauma Surg. 2002;122(3):148-55. https://doi.org/10.1007/s00402-001-0356-5.

23. Wuisman P, Lieshout O, Sugihara S, van Dijk M. Total sacrectomy and reconstruction: oncologic and functional outcome. Clin Orthop Relat Res. 2000:381:192-203. https://doi. org/10.1097/00003086-200012000-00023.

24. Frankel HC, Hancocck DO, Hyslop G, Malzak J, Michaelis LS, Ungar GH, et al. The value of postural reduction in the initial management of closed injuries of the spine with paraplegia and tetraplegia.Spinal Cord. 1969;7:179. https://doi.org/10.1038/sc.1969.30.

25. Knuf KM, Maani CV, Cummings AK. Clinical agreement in the American Society of Anesthesiologists physical status classification. Perioper Med (Lond). 2018;7:14 https://doi.org/10.1186/s13741-018-0094-7.

26. Oken MM, Creech RH, Tormey DC, Horton J, Davis TE, McFadden ET, et al. Toxicity and response criteria of the Eastern cooperative oncology group. Am J Clin Oncol. $1982 ; 5(6): 649-55$ 